\title{
A música como linguagem e comunicação à luz do estudo teológico-pastoral
}

\author{
Orientador: Prof. Abimar Oliveira de Moraes \\ Pesquisadora: Isabelle Christina Teixeira Fonseca \\ Fonte: $\mathrm{CNPq}$
}

\section{Introdução}

A presente pesquisa nasce a partir de uma relação entre minha experiência na comunidade eclesial - especialmente relacionada com os conceitos abordados: música, juventude e pastoral - e o convite de meu orientador, para que, de forma teórica, fosse possível o aprofundamento desta experiência e do pensamento crítico, e analogamente, contribuir para o enriquecimento do estudo teológico-pastoral.

Atualmente, vivemos um momento de transformações culturais movidas pelo avanço acelerado de inovações tecnológicas que desembocam em novas perspectivas de valores e paradigmas. Estas mudanças tem gerado uma crise das instituições que antes determinavam a vivência sócio-cultural. Neste movimento, percebe-se na sociedade atual uma destituição das estruturas que forneciam os referencias existenciais, guiando, desta forma, a vida em comum. Inserida de tal forma, a relação entre a Igreja e a sociedade revela-se desafiada. Neste contexto, a juventude se apresenta como o setor mais afetado pelas perda dos referenciais e como o setor mais difícil de ser alcançado pela Igreja.

Tal descompasso foi apontado pelo Concílio Vaticano II, que indicou a necessidade da busca por uma linguagem atualizada que possa alcançar a sociedade hodierna. Para isto, o Concílio enfatizou a essencialidade de uma Igreja aberta ao diálogo e atenta aos sinais dos tempos, como forma de resposta para esta geração. Segundo o Concílio, esta abertura se dará através de uma reconfiguração estrutural, que apresente uma nova linguagem.

Esta noção imprescindível do "novo" gerou uma cinesia eclesial que afluiu no surgimento de novos movimentos e iniciativas. Dentre estes movimentos, 
cabe destacar a reforma litúrgica, a RCC e as CEBS que agregaram novos elementos para uma renovada evangelização.

É neste passo que nos deparamos nos últimos anos, no desembocar dessas novas realidades eclesiais, com a manifestação e consolidação dos ministérios de música, que procuram, primordialmente, dialogar por meio da música com o universo juvenil. Neste contexto, e de forma prioritária para a intencionalidade deste estudo, a música emerge como um local antropológico privilegiado de comunicação e contato entre a comunidade eclesial, a juventude e tais ministérios. Neste local é possível encontrar um terreno propício para o desenvolvimento e a formação de identidades, convivência, expressão da própria afetividade e interioridade. No que tange o eixo pastoral da presente pesquisa, é importante destacar que o desenvolvimento destes aspectos são elementos que contribuem para o crescimento e a maturação de uma subjetividade que esteja aberta a relação com Deus, consigo, com o outro e com o todo.

Dada esta trajetória, tal estudo se debruçou, primeiramente, sobre os principais aspectos da música como fato sócio-cultural, mapeando e delineando seus significados. De forma similar, conhecendo o que lhe é natural, suas riquezas e limites. Por meio dos elementos resultantes desta primeira etapa, coube-nos (e cabe-nos) discernir de que forma se dá a harmonização da música com a mensagem cristã em prol da pastoral.

\section{Objetivos}

Estudar a música como linguagem e comunicação, inserida em um contexto histórico-cultural.

Verificar o funcionamento da música como elemento unificador e formador de identidades da juventude contemporânea, assim como, seu papel na estrutura dialogal e interpessoal deste grupo.

Analisar a música como instrumento pedagógico-cultural que pode e deve ser utilizado na evangelização dos jovens, isto é, na pastoral.

Apresentar, a partir desta análise, a relação harmônica da música com a mensagem cristã, visando uma melhor integração entre Igreja e juventude. 